\title{
Anti-Skin Aging Effect of Syriacusins from Hibiscus Syriacus on Ultraviolet-Irradiated Human Dermal Fibroblast Cells
}

\author{
In-Ja RYoo ${ }^{1}$, Eun-Yi MooN ${ }^{2}$, Young-Hee KIM ${ }^{1}$, Ik-soo LeE ${ }^{1}$, Soo-Jin CHоо ${ }^{1}$, KiHwan BAE ${ }^{3, *}$, and Ick-Dong Yoo ${ }^{1, *}$ \\ ${ }^{1}$ Korea Research Institute of Bioscience and Biotechnology, Daejeon 305-806, \\ ${ }^{2}$ Department of Bioscience and Biotechnology, Sejong University, Seoul 143-747, \\ ${ }^{3}$ College of Pharmacy, Chungnam National University, Daejeon 305-764, Republic of Korea
}

(Received May 7, 2010; Revised May 8, 2010; Accepted May 21, 2010)

\begin{abstract}
Photosensitized peroxidation of membrane lipids has been implicated in skin pathologies such as phototoxicity and premature aging. We have previously reported that syriacusin compounds isolated from Hibiscus Syriacus inhibited lipid peroxidation. Here, we investigated whether syriacusins could be effective inhibitor to skin aging using ultraviolet-irradiated human dermal fibroblast cells (HDFCs). Syriacusins A, B, and $C$ inhibit the activity of human neutrophil elastase (HNE), a serine protease to degrade extracellular matrix $(\mathrm{ECM})$ proteins including elastin, with $\mathrm{IC}_{50} \mathrm{~S}$ of $8.0,5.2$, and $6.1 \mu \mathrm{M}$, respectively. No changes in cell viability were detected by syriacusins $A$ and $B$ in UV-B $\left(10 \mathrm{~mJ} / \mathrm{cm}^{2}\right)$ irradiated HDFCs. Matrix metalloproteinase (MMP)-1 expression in HDFCs was increased by UV-B irradiation. MMP-1 expression in UV-B irradiated HDFCs was decreased by $10 \mu \mathrm{M}$ and $20 \mu \mathrm{M}$ syriacusin $\mathrm{A}$ to $50 \%$ and $20 \%$ of untreated control, respectively. Syriacusin B treated with $20 \mu \mathrm{M}$ reduced MMP-1 expression in UV-B irradiated HDFCs to $60 \%$ of untreated control. Syriacusin A also inhibited MMP-2 expression accompanying the increase of type-I pro-collagen in UV-B irradiated HDFCs. These results demonstrate that syriacusin A could be a more effective compound to inhibit skin aging caused by UV irradiation. It suggests that syriacusins $A$ and $B$ might be developed as possible agents to treat or prevent skin aging.
\end{abstract}

Keywords: Syriacusin, Hibiscus syriacus, MMP-1, Pro-collagen, Human dermal fibroblast

\section{INTRODUCTION}

Skin aging is a complex biological process that affects skin function and appearance. Skin connective tissue contains several types of collagen, elastin, fibronectin, proteoglycan and other extracellular matrix (ECM) proteins, among which type-I collagen is the most abundant. (Kligman, 1969; Bernstein et al., 1994; Rittie and Fisher, 2002). Human skin aging resulting from ultraviolet (UV) irradiation is a cumulative process that occurs based on the degree of exposure to sunlight (Imokawa, 2008; Imokawa, 2009). Quantitative and qualitative changes in the dermal ECM proteins are associated with photo-damage and eventually skin aging (Imokawa, 2009).

Elastin is an important structural protein of ECM and the

${ }^{*}$ Corresponding authors

Tel: +82-42-860-4330 (ID Yoo), +82-42-821-5925 (KH Bea)

Fax: +82-42-821-5925 (ID Yoo), +82-42823-6566 (KH Bea)

E-mail: idyoo@kribb.re.kr (ID Yoo), baekh@cnu.ac.kr (KH Bea) major component of elastic fibers that provides resilience and elasticity to many tissues including skin, lungs, ligaments and arterial walls (Wiedow et al., 1990; Tsukahara et al., 2006). The reduction of elastin in skin plays a role in the formation of wrinkles (Tsuji et al., 2001). Human neutrophil elastase (HNE) is a serine protease located primarily in the azurophil granules of polymorphonuclear leukocytes. HNE has a broad substrate specificity being able to degrade ECM proteins such as elastin, collagen, fibronectin, laminin, proteoglycan (Wiedow et al., 1990; Tsuji et al., 2001; Tsukahara et al., 2006) and the other connective tissue proteins such as cartilage tissues (Antonicelli et al., 2007). Biologically, elastase activity increases significantly with age and results in reduced skin elasticitic properties (Labat-Robert et al., 2000; Tsukahara et al., 2001; Tzaphlidou, 2004). Inhibition of elastase activity may protect skin aging (Kim et al., 2009; Xu et al., 2010).

The matrix metalloproteinases (MMPs) are a family of structurally related zinc-dependent endopeptidases that can degrade a wide variety of extracellular matrix compo- 
nents (Kahari and Saarialho-Kere, 1997). These can be classified into the following subgroups: collagenases, gelatinases, stromelysins, membrane-type MMPs and other MMPs on the basis of their structures and substrate specificities (Rittie and Fisher, 2002). MMP expression is low in unstimulated skin cells and healthy tissues but some MMPs are induced by various extracellular stimuli, such as UV or infrared radiation, growth factors, cytokines and tumor promoters (Rittie and Fisher, 2002; Imokawa, 2009). Gelatinase (i.e. MMP-2 and MMP-9) activities were increased by a chronical exposure to UV-B in hairless mice (Inomata et al., 2003; Suganuma et al., 2010). The inhibition of gelatinase activities suppresses UV-B-induced epidermal thickness enhancement and wrinkle formation (Inomata et al., 2003; Suganuma et al., 2010). MMP-1 is the major enzyme responsible for collagen 1 digestion (Dong et al., 2008). MMP-1 is induced by exposure to sunlight and released from damaged epidermal keratinocytes (Fagot et al., 2004) and the fibroblasts (Fagot et al., 2002; Dong et al., 2008). The level of partially degraded collagen is approximately 3.6-fold greater in photodamaged skin than in sun-protected skin (Varani et al., 2001).

The genus Hibiscus is widely distributed over Korea, China, India and Siberia. The dried flowers and root bark of $H$. syriacus are used as a folk medicine in the Orient $(\mathrm{Hsu}$ et al., 1986; Huang, 1993). Active constituents in methanol extract of the root bark of $H$. syriacus are three naphthalene compounds, syriacusins $A, B$, and $C$, with the inhibitory effect on lipid peroxidation (Yoo et al., 1998). Photosensitized peroxidation of membrane lipids has been implicated in skin pathologies such as phototoxicity, premature aging, and carcinogenesis (Girotti and Kriska, 2004). However, little has been known about the effect of syriacusins on photo-damaged skin.

Here, we investigated whether syriacusins could be effective inhibitor to skin aging by photodamage. We irradiated human dermal fibroblast cells (HDFCs) with UV-B below cytotoxicity energy level. Data showed that syriacusins $A, B$, and $C$ inhibit HNE activity and the expression of MMP-1 and MMP-2, which led to the increased expression of pro-collagen in HDFCs. It suggests that syriacusins $A$ and $B$ might be developed as possible agents to treat or prevent skin aging by photodamage.

\section{MATERIALS AND METHODS}

\section{Plant materials}

Hibiscus syriacus was collected at Yuseong, Chungnam Province, Korea, and identified by staff at the Korea Research Institute of Bioscience and Biotechnology (KRIBB),
Korea. A voucher specimen is deposited in the herbarium of KRIBB.

\section{Extraction and isolation of active constituents from Hibiscus syriacus}

Active ingredients were extracted and isolated by the described previously method (Yoo et al., 1998). Briefly, the dried root bark and of $H$. syriacus $(1.6 \mathrm{~kg}$ ) were extracted twice with methanol for 2 days at room temperature and then the extracts were partitioned by $n$-hexane, chloroform, ethyl acetate and $n$-butanol in turn. Among them, chloroform layer was subjected to colomn chromatography over a silica gel eluting with $n$-hexane:EtOAc (10:1-1:1, v/v) gradient system. Fractions were collected and combined by monitoring with HNE inhibitory activity in combination with analytical TLC to yieled subfractions 1-1 and 1-2. Subfraction 1-1 was rechromatographed on silica gel column eluting with same solvents as described above, and then purified by Sephadex $\mathrm{LH}-2 \mathrm{O}$ with $\mathrm{CHCl}_{3}-\mathrm{MeOH}$ (1:1). Syriacusin A (35.5 mg) was finally purified from subfraction $1-1$ by HPLC on a Senshu pak ODS column (20× $250 \mathrm{~mm}$ ) with $70 \%$ aq. $\mathrm{MeOH}$ at $8 \mathrm{ml} \mathrm{min}^{-1}$. Subfraction 1-2 was further purified by column chromatograpy over silica gel eltuting with $\mathrm{CHCl}_{3}-\mathrm{MeOH}(100: 1$ to $1: 1)$ followed by

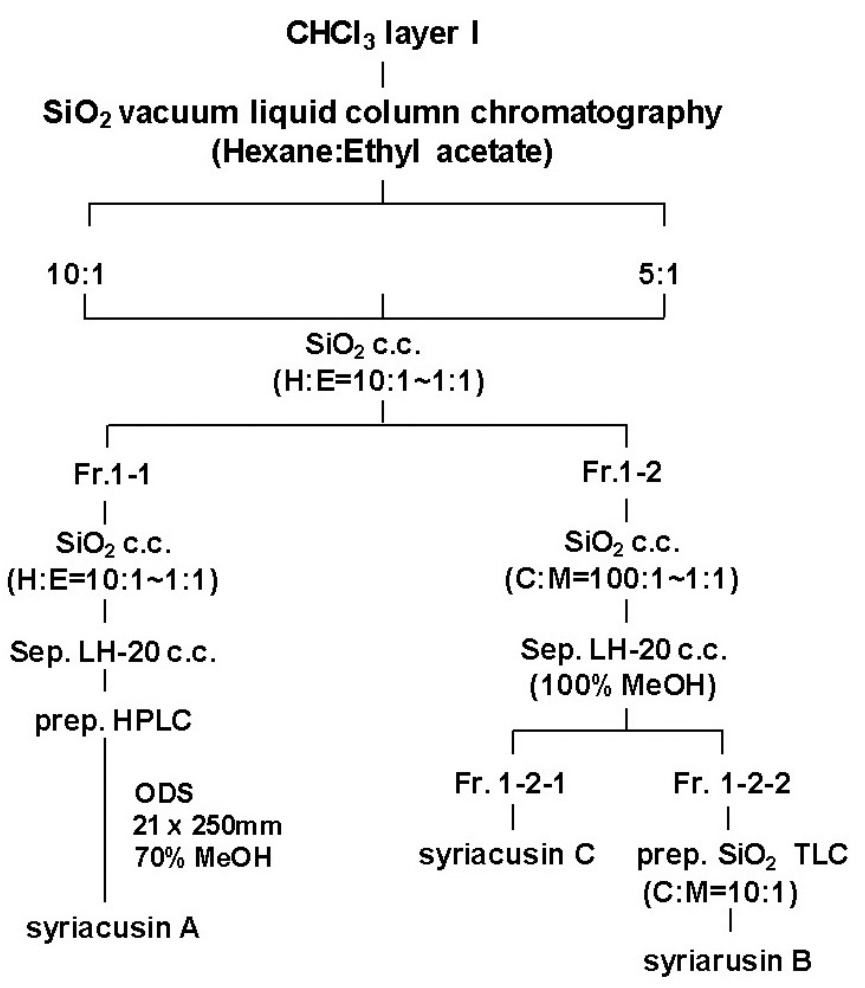

Fig. 1. Isolation procedure of syriacusins $A, B$, and $C$ from Hibiscus syriacus. 
<smiles>COc1c(CO)cc2ccc(O)c(C=O)c2c1OC</smiles>

syriacusin A

syriacusin B

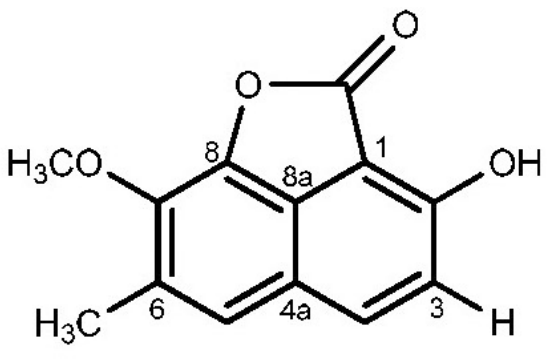

syriacusin C

Fig. 2. Chemical structure of syriacusins $A, B$, and $C$.

Sephadex LH-20 with methanol, to give syriacusin C (3 $\mathrm{mg}$ ) and another active subfraction 1-2-2. Syriacusin B (3.5 mg) was purified from subfraction 1-2-2 by silica gel prep TLC developed with $\mathrm{CHCl}_{3}-\mathrm{MeOH}(10: 1)$ (Fig.1, 2). For the bioassy test, compounds were dissolved in DMSO at $100 \mathrm{mM}$ and stored at $-20^{\circ} \mathrm{C}$. Epigallocatechin gallate (EGCG) was used as a positive control.

\section{Instrumental analysis}

NMR spectra were recorded on Varian UNITY 300 spectrometer at 300 and $500 \mathrm{MHz}$ for ${ }^{1} \mathrm{H}$, and 75 and 125 $\mathrm{MHz}$ for ${ }^{13} \mathrm{C}$ in $\mathrm{CDCl}_{3}+\mathrm{CD}_{3} \mathrm{OD}$ (1:1), $\mathrm{CDCl}_{3}$ and DMSO- $d_{6}$ with TMS as an internal standard. Complete proton and carbon assignments were based in $1 \mathrm{D}\left({ }^{1} \mathrm{H},{ }^{13} \mathrm{C}, \mathrm{DEPT}\right)$ and $2 \mathrm{D}\left({ }^{1} \mathrm{H}-{ }^{1} \mathrm{H}\right.$ COSY, ${ }^{1} \mathrm{H}-{ }^{13} \mathrm{C} \mathrm{HMQC},{ }^{1} \mathrm{H}-{ }^{13} \mathrm{C}$ HMBC) NMR experiments. Mass spectra (HREI-MS) were measured using a JMS-SX 102A (JEOL). HPLC was performed on a Senshu pak ODS column $(20 \times 250 \mathrm{~mm}$, YMC, RP-18, Japan) using a $\mathrm{H}_{2} \mathrm{O}-\mathrm{MeOH}$ system and by monitoring with a photodiode-array detector (Waters 515 pump, 2,996 photodiode array detector, USA). HNE (Calbiochem) inhibitory activity was measured according to the ELISA reader VersaMax (Molecular Devices, USA).

\section{Cell culture}

Human skin fibrobrast cells (CRL-2076) were purchased from the American Type Culture Collection (ATCC). Cell were cultured in Dulbeccos's Eagle's medium (DMEM: Gibco) supplemented with penicillin A (100 U/ml), streptomycin $(100 \mathrm{U} / \mathrm{ml})$, and $10 \%$ heat-inactivated fetal bovine serum (Gibco). Cells were maintained in a humidified incubator $5 \% \mathrm{CO}_{2}$ atmosphere at $37^{\circ} \mathrm{C}$

\section{MTT assay}

The tetrazolium dye colorimetric test was used to determine the viability of fibrobrast cells (Denizot and Lang, 1986). For treatment, cells were maintained on culture media without FBS for $24 \mathrm{~h}$ and UV-B irradiation. Then, cells were treated with syriacusins at concentrations range from $0,3,10$, and $30 \mu \mathrm{M}$. MTT solution was added after an incubation period of $48 \mathrm{~h}$. Cells were incubated at $37^{\circ} \mathrm{C}$ for an additional $3 \mathrm{~h}$. The supernatant was then removed, and $150 \mu \mathrm{l}$ of dimethyl sulfoxide (DMSO) was added. Absorbance was measured on a microplate reader at $570 \mathrm{~nm}$ to obtain the percentage of viable cells as compared to control group.

\section{UV irradiation}

Human dermal fibroblast cells (HDFCs) were grown in 6-well culture plate (BD Falcon) and maintained in culture media without FBS overnight. The cells were rinsed twice with phosphate-buffered saline (PBS), and the cells were exposed to UV light under a thin layer of PBS (Gibco). Cells were immediately washed with PBS after irradiation. Then, cells were cultured for $48 \mathrm{~h}$ in the serum-free media with or without syriacusins. The same conditions without UV irradiation were used for the control group.

\section{Human neutrophile elastase (HNE) assay}

The HNE inhibitory activity of syriacusins A, B, and C were evaluated using a previously described procedure (Kim et al., 2009; Xu et al., 2010). Briefly, each well of 96-well plate containing $40 \mu \mathrm{l}$ of substrate solution [1.4 mM $\mathrm{N}$-methoxysuccinyl-ala-ala-pro-val-p-nitroanilide in $10 \mathrm{mM}$ Tris- $\mathrm{HCl}$ buffer $(\mathrm{pH} 7.5)], 50 \mu \mathrm{l}$ of test solution (stock solutions of the test compounds were dissolved in DMSO and diluted with Tris- $\mathrm{HCl}$ buffer to give the final sample concentrations), adding $10 \mu \mathrm{l}$ of an enzyme solution ( 0.18 units $\mathrm{HNE}$ ) were mixed and incubated for $1 \mathrm{~h}$ at $37^{\circ} \mathrm{C}$ in the dark. After the reaction was quenched by adding $100 \mu$ of soybean trypsin inhibitor at a concentration of $0.2 \mathrm{mg} / \mathrm{ml}$, and the absorbance was immediately measured at $405 \mathrm{~nm}$ using ELISA reader. HNE inhibitory activity was expressed as follows: 
HNE inhibitory activity $(\%)=(1-\stackrel{A b-A s}{A b}) \times 100$

Ab: absorbance of blank

As: absorbance of sample

\section{Western blot analysis}

Cells were lysed in ice-cold lysis buffer containing $0.5 \%$ Nonidet P-40 (v/v) in $20 \mathrm{mM}$ Tris- $\mathrm{HCl}(\mathrm{pH} 8.3) ; 150 \mathrm{mM}$ $\mathrm{NaCl}$; protease inhibitors $(2 \mu \mathrm{g} / \mathrm{ml}$ aprotinin, pepstatin, and chymostatin; $1 \mu \mathrm{g} / \mathrm{ml}$ leupeptin and pepstatin; $1 \mathrm{mM}$ phenylmethyl sulfonyl fluoride (PMSF); and $1 \mathrm{mM} \mathrm{Na}_{4} \mathrm{VO}_{3}$. Lysates were incubated for 30 minutes on ice before centrifugation at $12,000 \times \mathrm{g}$ for 5 minutes at $4^{\circ} \mathrm{C}$. Proteins in the supernatant were denatured by boiling for 5 minutes in sodium dodecyl sulfate (SDS) sample buffer. Proteins in equal volume of conditioned culture media or equal number of cells were separated by $10 \%$ SDS-PAGE and transferred to a nitrocellulose membrane (Amersham international). To block the non-specific interaction between, membranes were incubated with $5 \%$ skim milk in Tris-buffered saline with Tween 20 (TBST) (10 mM Tris- $\mathrm{HCl}, \mathrm{pH}$ 7.6; 150 $\mathrm{mM} \mathrm{NaCl}$; $0.5 \%$ Tween 20) for $1 \mathrm{~h}$. To determine the amounts of MMP-1 (42/46 kDa) and type-I pro-collagen (170-190 kDa) secreted into culture media, membranes were incubated with the monocolnal anti-MMP-1 antibody (Calbiochem) and polyclonal anti-pro-collagen type-I antibody (Santa Cruz Biotechnology Inc.) diluted at 1:1,000 and 1:500, respectively. Bound antibodies were incubated with HRP- conjugated anti-mouse IgG and anti-goat IgG antibody as a secondaty antibody diluted at $1: 1,000$ and 1:500 dilution, respectively. Molecules were detected with the use of enhanced ECL system (Amersham international). Signal strength of each molecule was quantified by using a densitometric program (TINA).

\section{Zymography for MMP-2}

MMP-2 was detected by zymography in $10 \%$ polyacrylamide gel containing $0.1 \%$ gelatin (invitrogen, USA) (Demeule et al., 2000). Insoluble debris was removed by centrifugation at $12,000 \mathrm{~g}$ for $5 \mathrm{~min}$ at $4^{\circ} \mathrm{C}$ and $15 \mu \mathrm{l}$ of su- pernatant was mixed with Tris-glycine SDS sample buffer $(2 \times)$ without reducing agent. Without boiling, $25 \mu$ of sample was loaded on to $10 \%$ SDS-PAGE. After electrophoresis, SDS gel was incubated with $1 \times$ zymogram renaturing buffer (Invitrogen, USA) for $30 \mathrm{~min}$ at room temperature. Then, $1 \times$ zymogram developing buffer (Invitrogen, USA) was added to the gel. After developing for 30 min, a developing buffer was exchanged with fresh $1 \times z y-$ mogram developing buffer. After the gel was incubated at $37^{\circ} \mathrm{C}$ overnight, the gel was stained with $0.05 \%$ Commassie Brilliant Blue solution and destained with destaining solution containing $10 \%$ acetic acid, $40 \%$ methanol until protein bands were clearly visible in a blue background.

\section{RESULTS}

\section{Inhibitory effect of syriacusins on huma neutrophile elastase (HNE) activity}

The chloroform soluble fraction of methanol extract from the root bark of Hibiscus syriacus had been bio-assayed for the isolation of active constituents (Fig. 1). Those are three naphthalene compounds, syriacusins $A, B$, and $C$ (Fig. 2).

Given that lipid peroxidation was inhibited by syriacusins A, B, and C (Yoo et al., 1998) and photosensitized peroxidation of membrane lipids has been implicated in skin aging (Girotti and Kriska, 2004), we examined the effect of syriacusins on HNE activity in human dermal fibroblast cells (HDFCs). Syriacusins were used at 4 different concentrations, $1,3,10$, and $30 \mu \mathrm{M}$. As shown in Table I, syriacusins $A, B$ and $C$ inhibit $H N E$ activity with $I_{50}$ s of 8.0, 5.2 , and $6.1 \mu \mathrm{M}$, respectively. Their effect were comparable to the positive control, (-)-epigallocatechin-3gallate (EGCG) with $\mathrm{IC}_{50}$ of $1.1 \mu \mathrm{M}$. It suggests that syriacusins could be a novel anti-skin aging agent to inhibit the degradation of elastin.

\section{Cell viability had not been changed by syriacusin $A$ and $B$}

To investigate whether the effects of syriacusins $A, B$ and $\mathrm{C}$ on the UVB-induced MMP-1 expression and MMP-2

Table I. Inhibitory effect of syriacusins A, B, and C on human neutrophile elastase (HNE) activity ${ }^{\mathrm{a}}$

\begin{tabular}{|c|c|c|c|c|c|}
\hline \multirow{2}{*}{ Compounds } & \multicolumn{4}{|c|}{ Inhibition ratio for $\mathrm{HNE}(\%)^{\mathrm{a}}$} & \multirow{2}{*}{$\mathrm{IC}_{50}(\mu \mathrm{M})$} \\
\hline & $1 \mu \mathrm{M}$ & $3 \mu \mathrm{M}$ & $10 \mu \mathrm{M}$ & $30 \mu \mathrm{M}$ & \\
\hline Syriacusin A & $19.7 \pm 1.6$ & $25.7 \pm 1.7$ & $51.9 \pm 1.1$ & $76.6 \pm 0.7$ & 8.0 \\
\hline Syriacusin B & $15.3 \pm 1.8$ & $30.1 \pm 2.1$ & $86.3 \pm 0.6$ & $93.3 \pm 1.2$ & 5.2 \\
\hline Syriacusin C & $16.5 \pm 2.2$ & $22.9 \pm 1.0$ & $74.4 \pm 1.2$ & $89.6 \pm 1.0$ & 6.1 \\
\hline$E G C G^{b}$ & $45.3 \pm 1.6$ & $63.0 \pm 0.5$ & $75.8 \pm 0.8$ & $83.2 \pm 1.2$ & 1.1 \\
\hline
\end{tabular}

${ }^{\mathrm{a}}$ Data are expressed as the means \pm S.D. $(\mathrm{n}=3)$, and $\mathrm{IC}_{50}$ indicated the concentration $(\mu \mathrm{M})$ at which the percentage inhibition of HNE activity was $50 \%,{ }^{b}$ EGCG, [(-)-epigallocatechin-3-gallate] was used as a positive control. 
expression in cultured human dermal fibroblast cells (HDFCs), cells were irradiated with $0,10,20$, and $30 \mathrm{~mJ} /$ $\mathrm{cm}^{2}$ of UV-B. Cell viability was more than $90 \%$ up to 10 $\mathrm{mJ} / \mathrm{cm}^{2}$ as compared to UV-B untreated control (Fig. 3A). When HDFCs were exposed to $10 \mathrm{~mJ} / \mathrm{cm}^{2}$ and immediately further incubated for $48 \mathrm{~h}$ in the presence of syriacusins $A, B$, and $C$ with the concentrations of 3,10 and 30 $\mu \mathrm{M}$, no changes were detected in cell viability as compared to syriacusins-untreated control (Fig. 3B). In the meanwhile, cell viability was significantly decreased by the incubation with syriacusin $\mathrm{C}$ at $10 \mu \mathrm{M}$ (data not shown). It demonstrates that syriacusins $A$ and $B$ could be safe compounds to treat UV-exposed skin.

\section{Syriacusin A and B inhibit the expression of MMP-1 and MMP-2}

Given that HNE degrade ECM proteins such as elastin

A.

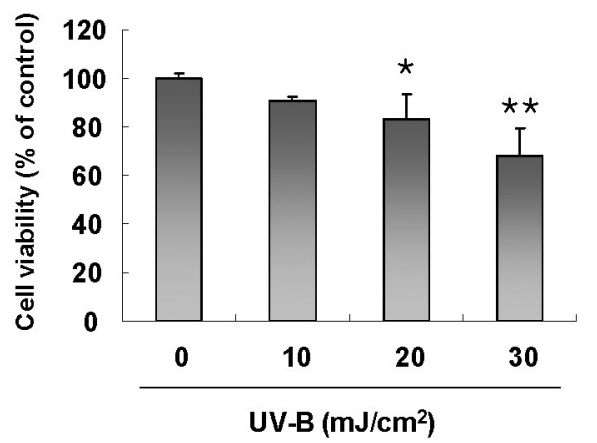

B.

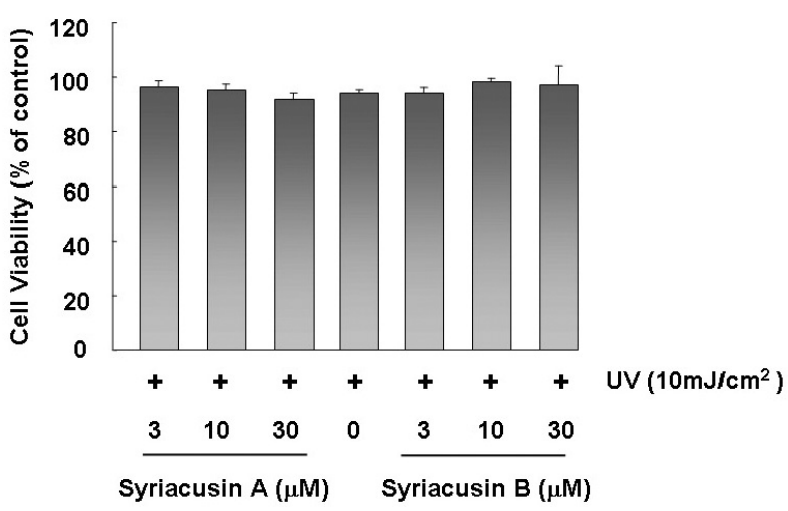

Fig. 3. Syriacusins $A$ and $B$ did not change cell viability exposed to UV-B irradiation. (A) Human dermal fibroblast cells (HDFCs) were irradiated with various energy of UV-B prior to incubation for 48. Cells viability of HDFCs was measured by MTT assay. Data represent mean \pm SED. ${ }^{*} p<0.05,{ }^{* *} p<0.01$, cell viability in UV-B irradiated-treated group was significantly different from control. (B) HDFCs were exposed to UV-B $\left(10 \mathrm{~mJ} / \mathrm{cm}^{2}\right)$ in the presence or absence of various concentrations of syriacusins $A$ and B. Cells viability of HDFCs was measured by MTT assay. and collagen (Wiedow et al., 1990; Tsuji et al., 2001; Tsukahara et al., 2006) and MMP-1 is the major enzyme responsible for collagen 1 digestion (Dong et al., 2008), we investigated the effect of syriacusins $A$ and $B$ on the expression of MMP-1 protein levels in HDFCs. Cells were irradiation with UVB $\left(10 \mathrm{~mJ} / \mathrm{cm}^{2}\right)$ and immediately incubated with $1,2,5,10$, and $20 \mu \mathrm{M}$ syriacusins $A$ or $B$ for $48 \mathrm{~h}$. As shown in Fig. 4A, syriacusin A inhibited UV-B-induced MMP-1 expression in a dose-dependent manner compared to the UV-B-irradiated control. MMP-1 expression in

A.
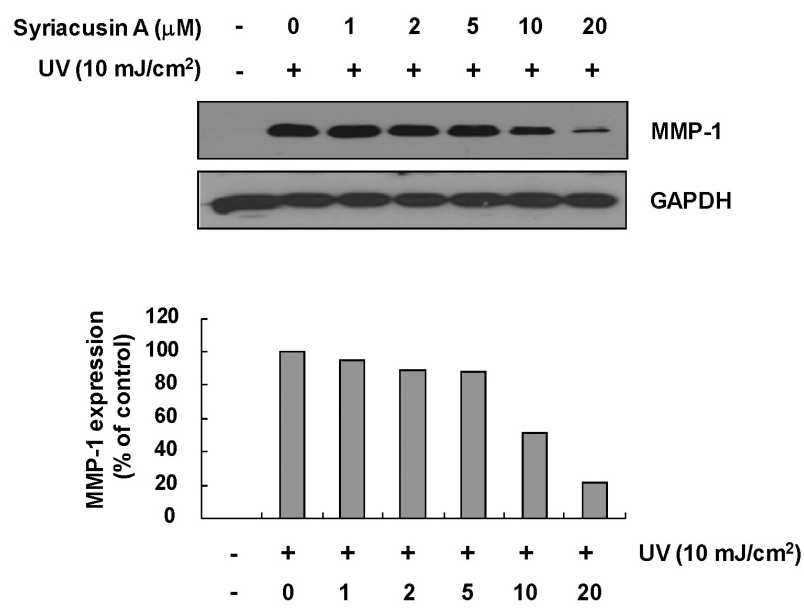

B.
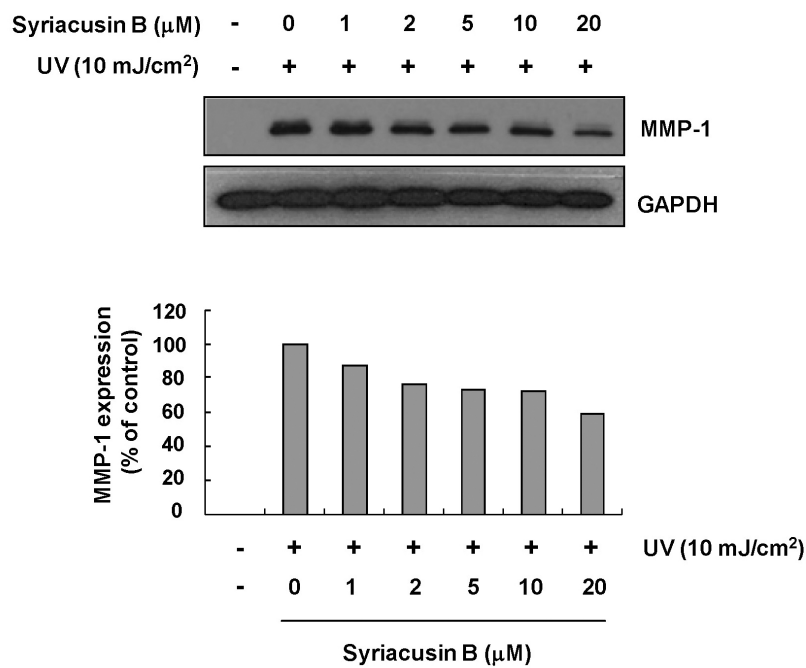

Fig. 4. UV-B-induced matrix metalloproteinase (MMP)-1 expression was inhibited by syriacusins $A$ and $B$ in human dermal fibroblast cells (HDFCs). (A) and (B) HDFCs were exposed to UV-B $\left(10 \mathrm{~mJ} / \mathrm{cm}^{2}\right)$ in the presence or absence of various concentrations of syriacusins $A$ and $B$, respectively. MMP-1 expression was detected by Western blot analysis as described in materials and methods. 


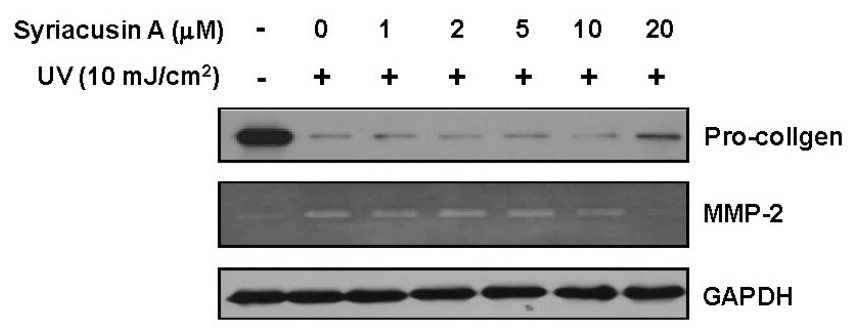

Fig. 5. Syriacusin A enhanced a production of pro-collagen and the enzyme activity of matrix metalloproteinase (MMP)-2 by UV-B irradiated human dermal fibroblast cells (HDFCs). HDFCs were exposed to UV-B $\left(10 \mathrm{~mJ} / \mathrm{cm}^{2}\right)$ in the presence or absence of various concentrations of syriacusin $A$. Pro-collagen and MMP-2 in UV-B irradiated HDFCs were detected by Western blot analysis and zymography, respectively as described in materials and methods.

UV-B irradiated HDFCs was decreased by $10 \mu \mathrm{M}$ and 20 $\mu \mathrm{M}$ syriacusin $\mathrm{A}$ to $50 \%$ and $20 \%$ of untreated control, respectively. However, syriacusin $B$ showed slightly decreased expression of MMP-1 (Fig. 4B). Syriacusin B treated with $20 \mu \mathrm{M}$ reduced MMP-1 expression in UV-B irradiated HDFCs to $60 \%$ of untreated control. It demonstrates that syriacusin $A$ could be a more effective compound to inhibit the degradation of collagen caused by UV irradiation.

\section{Pro-collagen expression was increased by syriacusin A}

To confirm the inhibitory effect of syriacusin A on MMP-1, we examined the effect of the production of type-I procollagen in UV-B-irradiated HDFCs. As shown in Fig. 5, the exposure of HDFCs to UV-B $\left(10 \mathrm{~mJ} / \mathrm{cm}^{2}\right)$ suppressed the level of type-I pro-collagen in the culture medium. However, the reduced type-I pro-collagen synthesis by UV-B irradiation was significantly attenuated by the incubation with syriacusin A at $20 \mu \mathrm{M}$.

Given that MMP-2 activities were increased by a chronical exposure to UV-B in hairless mice (Inomata et al., 2003; Suganuma et al., 2010) and the inhibition of gelatinase activities suppresses UV-B-induced wrinkle formation (Inomata et al., 2003; Suganuma et al., 2010), we measured the changes of MMP-2 activity caused by UV-B irradiation in HDFCs. As shown in Fig. 5, the exposure of HDFCs to UV-B $\left(10 \mathrm{~mJ} / \mathrm{cm}^{2}\right)$ enhanced MMP-2 expression. When HDFCs were incubated with syriacusin $A$ at $20 \mu \mathrm{M}$ immediately after UV-B irradiation, the increased MMP-2 expression was significantly attenuated to control level. It suggests that syriacusins $A$ and $B$ might be developed as possible agents to treat or prevent skin aging.

\section{DISCUSSION}

Regarding the environmental damage to skin, the most common physical injury is caused by UV irradiation. Photoaged skin is biochemically characterized by predominance of abnormal elastic fibers in the dermis and by a dramatic decrease in distinct interstitial collagens. Elastin is an important component of elastic fibers and also involved in inhibiting or repairing wrinkle formation (Labat-Robert et al., 2000), although collagen is a major factor in the skin. Elastase is a metalloproteinase which acts on degradation of elastin (Labat-Robert et al., 2000; Tsukahara et al., 2001; Tzaphlidou, 2004). It is known that elastase activity is increased by UV-B irradiation (Kim et al., 2009; Xu et al., 2010). MMP-mediated collagen damage is a major contributor to the phenotype of photoaged human skin (Varani et al., 2001). Hence, development of MMP inhibitor is considered to be a promising strategy for skin prevention and/or treatment of UV-induced skin damage (Inomata et al., 2003; Suganuma et al., 2010). We have examined the anti-wrinkle effects of various plant extracts including syriacusins A, B and C isolated from Hibiscus syriacus by screening the inhibitory effect on human neutophil elastase (HNE). We also investigate whether syriacusins A, B and $C$ are effective on the inhibition of UVB-induced MMP-1 expression and the production of type-I procollagen expression in cultured HDFCs. Data showed that syriacusin A inhibited UV-induced MMP-1 expression and enzymatic activity of MMP-2 and increased type-1 procollagen synthesis in UV-B irradiated HDFCs. However, a little inhibition to MMP-1 expression was shown by syriacusin $B$ and a poor cell viability was detected by syriacusin $\mathrm{C}$. It suggests that syriacusin A could be a more effective compound to inhibit skin aging caused by UV irradiation than syriacusin $\mathrm{B}$ or $\mathrm{C}$.

UV irradiation is known to provoke oxidative stress through the generation of reactive oxygen species (ROS) in cells (Lee et al., 1999; Tsukahara et al., 2006; Imokawa, 2008; Imokawa, 2009). ROS generation could results in the subsequent activation of complex signaling pathways, followed by the damage on DNA in skin cell (Dong et al., 2008; Imokawa, 2008). Earlier investigations indicated that the MAP kinase-mediated signal transduction plays an important role in the regulating a variety of cellular functions, including MMP-1 expression (Reunanen et al., 2002; Di Girolamo et al., 2003; Cortez et al., 2007), type-I collagen (Amemiya et al., 1999; Touyz et al., 2001) and elastin (Choi et al., 2009) synthesis. Our result revealed that syriacusin A had no inhibitory effect on the intracellular ROS levels (data not shown). It implicates that the inhibitory ef- 
fect of syriacusin A on MMP-1 is not mediated by its antioxidant effect but may be resulted from the modulation of another intracellular signal transduction molecules. It is required to define the effects of syriacusin A on the cell signal pathways in the further study

Collectively, syriacusins A, B and C were isolated from the Hibiscus syriacus. Among them, syriacusin A reduced the expression of MMP-1/2 and induced the expression of type-1 procollagen at the protein level in UV-irradiated cultured HDFCs. It suggests that syriacusin A might be developed as a possible agent to treat or prevent skin aging.

\section{ACKNOWLEDGMENTS}

This study was supported by a grant from the Korea Health 21 R\&D Project, Ministry of Health \& Welfare, Republic of Korea (A-050432).

\section{REFERENCES}

Amemiya, T., Sasamura, H., Mifune, M., Kitamura, Y., Hirahashi, J., Hayashi, M. and Saruta, T. (1999). Vascular endothelial growth factor activates MAP kinase and enhances collagen synthesis in human mesangial cells. Kidney Int. 56, 20552063.

Antonicelli, F., Bellon, G., Debelle, L. and Hornebeck, W. (2007). Elastin-elastases and inflamm-aging. Curr. Top. Dev. Biol. 79, 99-155.

Bernstein, E. F., Chen, Y. Q., Tamai, K., Shepley, K. J., Resnik, K. S., Zhang, H., Tuan, R., Mauviel, A. and Uitto, J. (1994). Enhanced elastin and fibrillin gene expression in chronically photodamaged skin. J. Invest. Dermatol. 103, 182-186.

Choi, W. S., Mitsumoto, A. and Kochevar, I. E. (2009). Involvement of reactive oxygen species in TGF-beta1-induced tropoelastin expression by human dermal fibroblasts. Photochem. Photobiol. 85, 1425-1433.

Cortez, D. M., Feldman, M. D., Mummidi, S., Valente, A. J., Steffensen, B., Vincenti, M., Barnes, J. L. and Chandrasekar, B. (2007). IL-17 stimulates MMP-1 expression in primary human cardiac fibroblasts via p38 MAPK- and ERK1/2dependent C/EBP-beta, NF-kappaB, and AP-1 activation. Am. J. Physiol. Heart Circ. Physiol. 293, H3356-3365.

Demeule, M., Brossard, M., Page, M., Gingras, D. and Beliveau, R. (2000). Matrix metalloproteinase inhibition by green tea catechins. Biochim. Biophys. Acta. 1478, 51-60.

Denizot, F. and Lang, R. (1986). Rapid colorimetric assay for cell growth and survival. Modifications to the tetrazolium dye procedure giving improved sensitivity and reliability. $J$. Immunol. Methods. 89, 271-277.

Di Girolamo, N., Coroneo, M. T. and Wakefield, D. (2003). UVBelicited induction of MMP-1 expression in human ocular surface epithelial cells is mediated through the ERK1/2 MAPK-dependent pathway. Invest. Ophthalmol. Vis. Sci. 44, 4705-4714.

Dong, K. K., Damaghi, N., Picart, S. D., Markova, N. G., Obayashi, K., Okano, Y., Masaki, H., Grether-Beck, S., Krutmann, J.,
Smiles, K. A. and Yarosh, D. B. (2008). UV-induced DNA damage initiates release of MMP-1 in human skin. Exp. Dermatol. 17, 1037-1044.

Fagot, D., Asselineau, D. and Bernerd, F. (2002). Direct role of human dermal fibroblasts and indirect participation of epidermal keratinocytes in MMP-1 production after UV-B irradiation. Arch. Dermatol. Res. 293, 576-583.

Fagot, D., Asselineau, D. and Bernerd, F. (2004). Matrix metalloproteinase-1 production observed after solar-simulated radiation exposure is assumed by dermal fibroblasts but involves a paracrine activation through epidermal keratinocytes. Photochem. Photobiol. 79, 499-505.

Girotti, A. W. and Kriska, T. (2004). Role of lipid hydroperoxides in photo-oxidative stress signaling. Antioxid. Redox. Signal. 6, 301-310.

Hsu, H. Y., Chen, Y. P., Shen, S. J., Hsu, C. S., Chen, C. C. and Chang, H. C. (1986). Oriental Material Medica, a Concise Guide, pp. 503-504. Healing Arts Institute, Taipei.

Huang, K. C., (1993). The Pharmacology of Chinese Herbs, pp. 193-194. CRC Press, Tokyo.

Imokawa, G. (2008). Recent advances in characterizing biological mechanisms underlying UV-induced wrinkles: a pivotal role of fibrobrast-derived elastase. Arch. Dermatol. Res. 300(Suppl 1), S7-20.

Imokawa, G. (2009). Mechanism of UVB-induced wrinkling of the skin: paracrine cytokine linkage between keratinocytes and fibroblasts leading to the stimulation of elastase. $J$. Investig. Dermatol. Symp. Proc. 14, 36-43.

Inomata, S., Matsunaga, Y., Amano, S., Takada, K., Kobayashi, K., Tsunenaga, M., Nishiyama, T., Kohno, Y. and Fukuda, M. (2003). Possible involvement of gelatinases in basement membrane damage and wrinkle formation in chronically ultraviolet B-exposed hairless mouse. J. Invest. Dermatol. $120,128-134$.

Kahari, V. M. and Saarialho-Kere, U. (1997). Matrix metalloproteinases in skin. Exp. Dermatol. 6, 199-213.

Kim, Y. H., Ryoo, I. J., Choo, S. J., Xu, G. H., Lee, S. K., Seok, S. J., Bae, K. H. and Yoo, I. D. (2009). Clitocybin D, a novel human neutrophil elastase inhibitor from the culture broth of clitocybe aurantiaca. J. Micro. Biotech. 19, 1139-1141.

Kligman, A. M. (1969). Early destructive effect of sunlight on human skin. JAMA 210, 2377-2380.

Labat-Robert, J., Fourtanier, A., Boyer-Lafargue, B. and Robert, L. (2000). Age dependent increase of elastase type protease activity in mouse skin. Effect of UV-irradiation. J. Photochem. Photobiol. B 57, 113-118.

Lee, S. J., Yun, Y. S., Lee, I. K., Ryoo, I. J., Yun, B. S. and Yoo, I. D. (1999). An antioxidant lignan and other constituents from the root bark of Hibiscus syriacus. Planta Med. 65, 658-660.

Reunanen, N., Li, S. P., Ahonen, M., Foschi, M., Han, J. and Kahari, V. M. (2002). Activation of p38 alpha MAPK enhances collagenase-1 (matrix metalloproteinase (MMP)-1) and stromelysin-1 (MMP-3) expression by mRNA stabilization. J. Biol. Chem. 277, 32360-32368.

Rittie, L. and Fisher, G. J. (2002). UV-light-induced signal cascades and skin aging. Ageing Res. Rev. 1, 705-720.

Suganuma, K., Nakajima, H., Ohtsuki, M. and Imokawa, G. (2010). Astaxanthin attenuates the UVA-induced up-regulation of matrix-metalloproteinase-1 and skin fibroblast elastase in human dermal fibroblasts. J. Dermatol. Sci. 58, 136-142. 
Touyz, R. M., He, G., El Mabrouk, M. and Schiffrin, E. L. (2001) p38 Map kinase regulates vascular smooth muscle cell collagen synthesis by angiotensin II in SHR but not in WKY. Hypertension 37, 574-580.

Tsuji, N., Moriwaki, S., Suzuki, Y., Takema, Y. and Imokawa, G. (2001). The role of elastases secreted by fibroblasts in wrinkle formation: implication through selective inhibition of elastase activity. Photochem Photobiol 74, 283-290.

Tsukahara, K., Nakagawa, H., Moriwaki, S., Takema, Y., Fujimura, T. and Imokawa, G. (2006). Inhibition of ultravioletB-induced wrinkle formation by an elastase-inhibiting herbal extract: implication for the mechanism underlying elastaseassociated wrinkles. Int. J. Dermatol. 45, 460-468.

Tsukahara, K., Takema, Y., Moriwaki, S., Tsuji, N., Suzuki, Y., Fujimura, T. and Imokawa, G. (2001). Selective inhibition of skin fibroblast elastase elicits a concentration-dependent prevention of ultraviolet B-induced wrinkle formation. $\mathrm{J}$. Invest. Dermatol. 117, 671-677.
Tzaphlidou, M. (2004). The role of collagen and elastin in aged skin: an image processing approach. Micron. 35, 173-177.

Varani, J., Spearman, D., Perone, P., Fligiel, S. E., Datta, S. C., Wang, Z. Q., Shao, Y., Kang, S., Fisher, G. J. and Voorhees, J. J. (2001). Inhibition of type I procollagen synthesis by damaged collagen in photoaged skin and by collagenasedegraded collagen in vitro. Am. J. Pathol. 158, 931-942.

Wiedow, O., Schroder, J. M., Gregory, H., Young, J. A. and Christophers, E. (1990). Elafin: an elastase-specific inhibitor of human skin. Purification, characterization, and complete amino acid sequence. J. Biol. Chem. 265, 14791-14795.

Xu, G. H., Kim, Y. H., Chi, S. W., Choo, S. J., Ryoo, I. J., Ahn, J. S. and Yoo, I. D. (2010). Evaluation of human neutrophil elastase inhibitory effect of iridoid glycosides from Hedyotis diffusa. Bioorg. Med. Chem. Lett. 20, 513-515.

Yoo, I. D., Yun, B. S., Lee, I. K., Ryoo, I. J., Choung, D. H. and Han, K. H. (1998). Three naphthalenes from root bark of Hibiscus syriacus. Phytochemistry 47, 799-802. 